\title{
Marking behavior of the giant anteater Myrmecophaga tridactyla (Mammalia: Myrmecophagidae) in Southern Brazil
}

\author{
Fernanda G. Braga'; Raphael E. F. Santos ${ }^{2} \&$ Antonio C. Batista'
}

\begin{abstract}
${ }^{1}$ Programa de Pós-Graduação em Engenharia Florestal, Universidade Federal do Paraná. Rua Professor Lothário Meissner 3400, Jardim Botânico, Campus III, 80210-170 Curitiba, Paraná, Brasil. E-mail: bragafg@netpar.com.br; batistaufpr@ufpr.br 2 Bio situ Projetos e Estudos Ambientais Ltda. Rua Carlos Belão 45, Vila Juliana, 83306-120 Piraquara, Paraná, Brasil. E-mail: raphael@biositu.com.br
\end{abstract}

\begin{abstract}
This research presents novel data on tree marking by the giant anteater, a large Neotropical mammal threatened in the state of Paraná and other areas of Brazil, and nearly threatened worldwide. Field work was carried out in the municipality of Jaguariaíva, Paraná (Southern Brazil) with the goal of evaluating the pine marking behavior of the giant anteater and ascertaining whether wildfires interfere with it. Anteater marks were searched for on the trunks of pine trees in stands as well as pine trees dispersed throughout the landscape. For each pine tree, the following features were recorded: height, diameter breast height (DBH), height of first branch, presence/absence of scratch marks, geographical location, substrate, and matrix. The total number of scratches, scratch directions, scratch length, and height of top mark were also recorded. The scratches were defined as horizontal or vertical. Tree scratching was directly observed in three instances. Ninety-one trees were measured in the study area. The differences between marked and non-marked pines were significant for $\mathrm{DBH}$ and height of first branch. All scratches were found on pines dispersed throughout the landscape. Trees with horizontal and vertical marks were significantly different in terms of $\mathrm{DBH}$, first branch height, and top mark height. After a wildfire that affected part of the study area, 54\% of the previously marked trees were marked anew. We suggest that the marking behavior is used for communication between conspecifics with overlapping home ranges, possibly during the mating season. Additionally, we advance the hypothesis that pine marking behavior becomes more frequent with increased population stress due to anthropic interference.
\end{abstract}

KEY WORDS. Behavior; Paraná; pilosa; pine; scratches.

The giant anteater, Myrmecophaga tridactyla (Linnaeus, 1758), is the largest known anteater species, and the only species in Myrmecophaga. Specimens range from 100-190 cm long and have a 64-90 $\mathrm{cm}$ long tail (EMmONs 1997). The fur of the giant anteater is very long from the nape to the tail, resembling a mane. The forelimbs are whitish and the hind limbs are black (VIEIRA 1949). The giant anteater has a long protruding tongue covered with sticky saliva produced by highly developed salivary glands (Rossoni et al. 1981, NowAK 1991). The forelimbs are very muscular and have four claws, three of which are longer than the five hind limb claws; claws may reach 6.5 $\mathrm{cm}$ in length (Chebez 1994). Sexual dimorphism is not evident in the giant anteater, a generally solitary species except during the mating season when male-female pairs can be observed. Myrmecophaga tridactyla is a threatened species, being considered critically endangered in the state of Paraná (MARgarido \& Braga 2004), and vulnerable in Brazil (IBAma 2003); worldwide, it is considered a near threatened species (IUCN 2008). In the last 200 years, the distribution area of the giant anteater has dwindled due to intensive degradation of its natural habitat
(PARera 2002). Furthermore, predatory hunting, attacks by domestic dogs, wildfires and roadkill incidents have also contributed to a decrease in anteater populations (FonseCA et al. 1994, Margarido \& Braga 2004). Due to a relatively low metabolism and low body temperature, the giant anteater is particularly vulnerable to attacks. The factors mentioned above, in association with a low energy level diet (a characteristic of the representatives of this group), low reproduction rates, and prolonged offspring care (FonseCA \& Aguiar 2004) put the long-term survival of the giant anteater in great danger. Although the giant anteater is one of the best-known Latin American species worldwide, little is known about the behavior, ecology, and physical abilities (Young et al. 2003) of this species.

The present study took place in the phytogeographic region called "Campos Gerais", comprising grasslands and savannahs located within the second Paraná state highlands (MAACK 1981). Herbaceous ligneous shrubs growing on rock outcrops and mostly poor and shallow soil (Veloso et al. 1991) predominate in this region. The expansion of agribusiness in the last decades and the substitution of traditional cattle rearing with 
monoculture and pine tree forest plantations have depleted the grassland areas as never before (Moro \& CARMo 2007). Second to the direct modification of the environment for profit, biological contamination in the form of invasion by exotic species is the greatest cause of environmental degradation (ZILLER \& GALVÃO 2002) in the area. The native grasslands are particularly susceptible to the invasion of an exotic species of pines that have small seeds which are easily disseminated. Pines are found in dry grasslands, wet grasslands, hillsides, valley bottoms, and rock outcrops, environments that are largely favourable to pine seed germination (WeIRICH Neto \& Rocha 2007).

Forest farming is an important economic activity in the municipality of Jaguariaíva, having the largest local impact (SANTOS 2007). Reforestation with pines is an important source of insertion of forest fragments when compared to other types of monoculture around natural areas. As pines disperse by anemochory, the biological contamination of grassland areas is favoured. Given the need to preserve the remnant vegetation, studies on the wildfires that naturally occur in these environments are badly needed.

The scratch marking behavior of the giant anteater has a role in claw sharpening, foraging and gathering food, and in (K. KREUTZ pers. comm.) territorial and mating behaviors. SHAW et al. (1985) were the first to record trunk marking by the giant anteater in the Serra da Canastra National Park, Central Brazil, where they observed an individual scratching a tree trunk with the forelimbs. REDFord (1985) reported that the giant anteater can climb trees to escape fires and Young et al. (2003) observed that individuals of this species can climb not only trees, but also termite mounds and even walls. Young et al. (2003) reported that termite mound scratches in the Serra da Canastra National Park were caused by anteaters climbing down the mound, rather than intentionally. K. KREUTz (pers. comm.), on the other hand, reported marks on the trunks of Acacia mangium Willd., 1806 and A. Auriculiformis A. Cunn. ex Benth., 1842 in plantations in Northern Brazil, providing the first data on anteater scratch marking behavior.

The present study evaluates the patterns of scratch marks made by anteaters on pine trees, and the influence of wildfires on tree scratching behavior.

\section{MATERIAL AND METHODS}

The present study was conducted in the municipality of Jaguariaíva $\left(24^{\circ} 15^{\prime} 95^{\prime \prime} \mathrm{S}, 49^{\circ} 42^{\prime} 34^{\prime \prime} \mathrm{W}\right)$, which lies in the Campos Gerais grassland of the state of Paraná (Fig. 1). The 8,000 ha area is an environmental mosaic composed of dry grasslands, wet grasslands, pastures, plantation areas, and Pinus spp. reforestation areas. For the evaluation of anteater scratch marks, we selected a section of ca 800 ha within the area mentioned above. The entire area is subjected to different environmental impacts, such as the destruction of natural environments for the establishment of grain and forest plantations, occasional wildfires, attacks by domestic dogs, and chemical pollution.

We collected data on pine scratch markings by the giant anteater between July 2007 and October 2008, as part of a broader Giant Anteater Monitoring Program. Only pine trees were surveyed because there were no other tree species in the area. We chose trees at random and recorded, for each tree

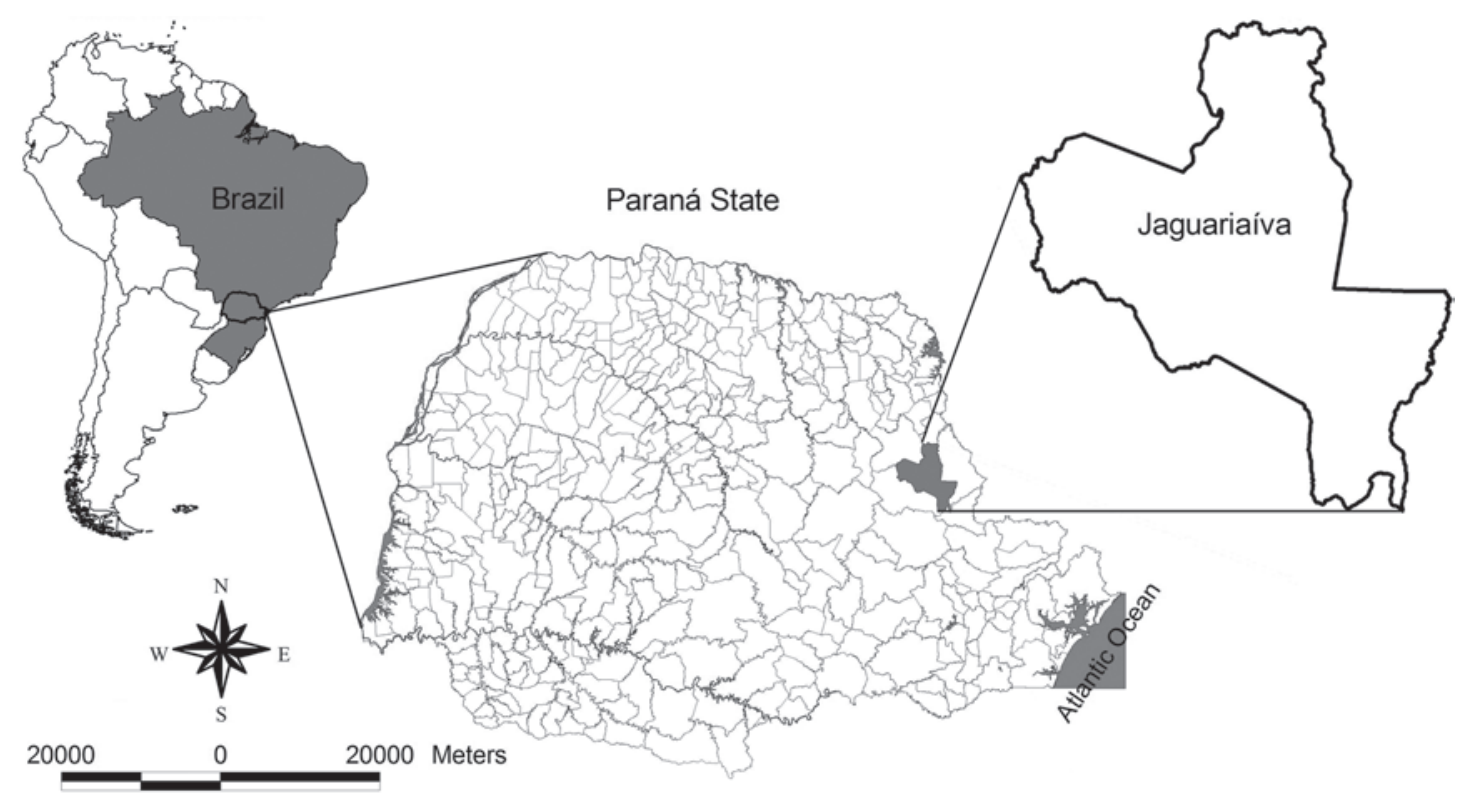

Figure 1. Location of the study area. 
chosen, the height, diameter breast height (DBH), height of the first branch, and the presence/absence of scratches. The geographical location of the tree, substrate (dry grassland, wet grassland, and rock outcrop) and matrix (pasture or cultivated field) of the location were recorded as well, for later analysis. When scratches were present, we also recorded the total number of scratches, scratch direction, scratch length, and height of top scratch.

In addition to the trees dispersed throughout the landscape, we also surveyed pines that were planted in stands. We randomly selected tree rows from each stand and examined their component trees, including the trees in the borderline. Scratches were classified into two categories: horizontal and vertical. When making horizontal scratches, the anteater uses one forelimb to strike the trunk laterally while leaving the three remaining limbs on the ground (Fig. 1); vertical scratches, on the other hand, are produced when the anteater uses both forelimbs to scratch the trunk while standing on the hind limbs (Figs 2 and 3).

\section{RESULTS}

The first scratching behavior on a pine tree was recorded on June 30, 2007 at 4:48 PM. This vertical- scratch was caused by an adult male ("AM") tagged with a radio transmitter. The second scratching event, also a vertical scratch, was observed on October $15^{\text {th }}, 2007$ at 5:13 p.m. The sex of the latter individual was not determined ("IA"). The third scratching event was observed on October $16^{\text {th }}, 2007$ at 4:08 p.m, caused by "AM" striking the tree trunk sideways with the right forelimb.

After observing the first scratching event, we searched for other scratched trees in the study area. We recorded a total of 91 dispersed pine trees in the landscape (as explained above, these trees belong to an adventive species and thus represent biological contamination). Scratches were observed in $41.7 \%$ of them $(n=38)$. The pines located in stands $(n=73)$ in either matrix (culture field or wet grassland) or substrate (dry grassland or wet grassland) did not have scratches.

The numbers of non-scratched and scratched trees were not significantly different $\left(\chi^{2}=4.1604, \mathrm{p}>0.05\right)$; however, these two tree groups presented some distinct characteristics, as shown in table I.

The scratched trees were taller in average and had higher $\mathrm{DBH}$ and first branch height than the non-scratched trees. Nevertheless, a comparison among scratched and non-scratched trees revealed significant differences only for DBH $\left(\chi^{2}=12.911\right.$, $\mathrm{p}<0.05)$ and first branch height $\left(\chi^{2}=59.754, \mathrm{p}<0.05\right)$.

The pine trees that had marks were dispersed in the landscape. The stand trees evaluated were $4.5 \mathrm{~m}( \pm 1.45)$ tall, had average DBH of $27 \mathrm{~cm}( \pm 9.97)$, and all presented branches at the base.

The numbers of horizontal and vertical scratches were also significantly different $\left(\chi^{2}=29.432, \mathrm{p}<0.05\right)$, with vertical scratches being more numerous than horizontal ones (Tab. II).

The following characteristics were significantly different

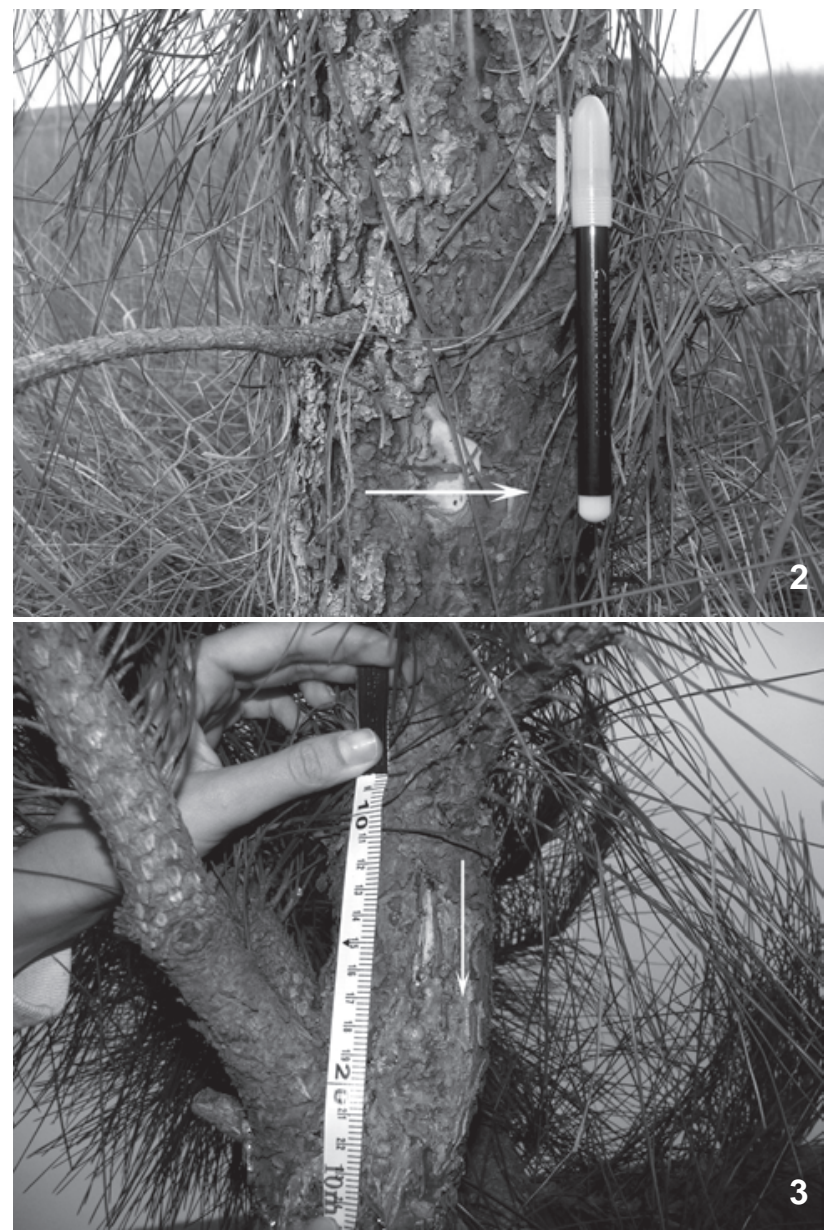

Figures 2-3. Horizontal (2) and vertical (3) scratches on a pine trunk made by the giant anteater.

for trees with horizontal and vertical scratches: DBH $\left(\chi^{2}=21.843, p<0.05\right)$, first branch height $\left(\chi^{2}=39.868\right.$, $\mathrm{p}<0.05)$, and top scratch height $\left(\chi^{2}=53.408, \mathrm{p}<0.05\right)$.

Of the 91 trees evaluated, $54.9 \%$ were located in wet grassland substrates $(\mathrm{n}=50), 40.6 \%$ in dry grassland $(\mathrm{n}=37)$, and $4.4 \%$ on rock outcrops $(\mathrm{n}=4)$. In dry and wet grasslands, 56.7 and $34 \%$ of the trees, respectively, were scratched $(n=21$ and $\mathrm{n}=17$ ), while on rock outcrop areas, no scratches were observed. Regarding the matrix, $65.9 \%$ of the trees were close to cultivated fields ( $n=60), 21.9 \%$ were close to pastures $(n=20)$, and $12.1 \%$ were close to roads $(n=4)$. Fifty-five percent of the trees in both pasture and cultivated fields were scratched. Pines alongside the roads, however, were not scratched.

In August 2008, a farmer slash burned an area of approximately 10 ha to clean the soil for planting. The pines in this area were evaluated before the wildfire $(n=31) ; 11$ were scratched. Three weeks after the wildfire, the trees were evaluated again, and six (54\%) of the 11 trees had been scratched again. 
Table I. Standard measurements of non-scratched and scratched trees in the study area.

\begin{tabular}{lcrr}
\hline Characteristics & All evaluated trees $(\mathrm{n}=91)$ & Non-scratched trees $(\mathrm{n}=53)$ & Scratched trees $(\mathrm{n}=38)$ \\
\hline Average tree height $(\mathrm{m})$ & $3.3 \pm 2.24$ & $3.0 \pm 2.19$ & $5.0 \pm 2.06$ \\
Average tree DBH $(\mathrm{cm})$ & $29.4 \pm 24.65$ & $23.6 \pm 15.33$ & $48.0 \pm 27.70$ \\
First branch height $(\mathrm{cm})$ & $94.0 \pm 65.70$ & $30.0 \pm 59.56$ & $133.0 \pm 65.70$ \\
\hline
\end{tabular}

Table II. Tree scratch measurements and recorded scratch direction.

\begin{tabular}{lrrr}
\hline \multirow{2}{*}{ Characteristics } & \multicolumn{3}{c}{ Scratched trees } \\
\cline { 2 - 4 } & Total $(\mathrm{n}=38)$ & Horizontal $(\mathrm{n}=2)$ & Vertical $(\mathrm{n}=36)$ \\
\hline Average tree height $(\mathrm{m})$ & $5.00 \pm 2.06$ & $3.5 \pm 0.42$ & $5.3 \pm 2.08$ \\
Average tree DBH $(\mathrm{cm})$ & $48.0 \pm 27.70$ & $16.5 \pm 10.60$ & $55.5 \pm 27.05$ \\
First branch height $(\mathrm{cm})$ & $133.0 \pm 56.29$ & $60.5 \pm 40.30$ & $140.0 \pm 54.66$ \\
Average number of scratches & $3.0 \pm 3.04$ & $2.5 \pm 0.70$ & $4.0 \pm 3.10$ \\
Average scratch length $(\mathrm{cm})$ & $6.8 \pm 5.52$ & $2.0 \pm 1.17$ & $7.05 \pm 5.53$ \\
Top scratch height $(\mathrm{cm})$ & $135.6 \pm 43.89$ & $50.5 \pm 4.94$ & $136.0 \pm 40.27$ \\
\hline
\end{tabular}

\section{DISCUSSION}

Our results are in agreement with those reported by Kolja Kreutz (Department of animal ecology and tropical biology, University Würzburg, Germany, pers. comm.) for Acacia sp. on the large preference of the giant anteater for trees with larger trunk diameters. Despite this agreement, the scratches recorded on Acacia sp. were more numerous in denser stands, whereas the present study has found evidence of scratching events only on trees that were relatively isolated from each other.

The larger number of scratches on trees with higher first branches may be related to the scratching behavior itself. Scratches and other characteristic signs were always rather apparent. Branches at the base of the trunk may hide the scratches and render them less visible to other giant anteaters. The apparent visibility of the scratches suggests that they have a communication function. Many species of mammals select conspicuous sites (BOWyer et al. 1994, RoBERTs 1997) that increase the likelihood that their marks will be found by target individuals. Because marking behaviors have high energy costs, they must be as efficient as possible. This may also explain the absence of scratches on trees in stands, because all of them had branches starting at the base. Another possible explanation for the absence of scratches on stand trees is that they would be less visible than the scratches made on landscapedispersed trees. Vertical scratches also more conspicuous than horizontal marks: they tend to be longer and stand higher up from the soil when compared with vertical marks.

In open areas, the absence of trees renders scratching impossible, and other signalling strategies may become necessary. According to F. Miranda (personal communication), in addition to tree scratching, giant anteaters can also perform scent marking via urination. The habitat of the giant anteater is presently being investigated in order to ascertain the size of the home range and the patterns of habitat use by this species. These investigations may reveal a correlation between marking and the use of the habitat in the region. The marking behavior is thought to be used for communication between conspecifics whose home ranges overlap, and may be related to the mating season. Two of the marking events were performed by the male "AM", while the "IA" performed the marking in an area known to be used by "AM". "AM" was observed on September 13 $3^{\text {th }}, 2007$ close to another individual, supposedly a female, as the giant anteater has solitary habits and adults pair up only during the mating season (Cabrera \& Yepes 1960). According to K. Kreutz (pers. comm.) this type of marking may result from greater intraspecific competition due to a high level of stress in agricultural areas. Even though the level of stress on the local population has not been investigated, it is expected to be very high because of the level of anthropic interference due to intense traffic of trucks and agricultural machines, the use of the area by domestic dogs, and the constant human presence.

Marking behavior has been reported for captive giant anteaters in Colombia, and may be a function of the stresses related to captivity. Males in the same enclosure marked the available trees but did so at distinct times Sol Angela O. Holguin and Carolina Casas (pers. comm. Fundação Buzco, Colombia).

Wild, captured and caged giant anteaters may lose their claws due to intense scratching, as reported by José R. Pachaly (Instituto de Pesquisa Estudos e Ambiência Científica, Brazil, pers. comm.), who associates this behavior with the high levels of stress. 
The behavior of the giant anteater was studied in presence of fire in Central Brazil and it was observed that it is affected by the intensity and frequency of fire events, population size, or even the resiliency of the environments affected by the fire. Maria A. Drumond (Universidade Federal de Minas Gerais, Brazil, pers. comm.) reported that fires do not alter the food availability, diet, and foraging behavior of the giant anteater in the short-term; however, the build-up of combustible materials by fire suppression in some areas may set the stage for large fires that reduces potential shelters, as well as food availability. SiLveIra et al. (1999) reported that the giant anteater is the large mammal most affected by wildfires as a consequence of the lethargy and long fur that characterize this species. This vulnerability can be devastating to small populations. The authors reported a total of 332 dead individuals after a fire at the Emas National Park, state of Goiás. The data gathered herein reflect the continued use of slash-burned areas by the species, which is confirmed by the marks made shortly after the fire. Even when the fire erases the old marks, some trees are marked anew, possibly because they are located within an individuals' home range.

It must be noted that the fire reported in this study was small and its effects cannot not be extrapolated to large fires or to areas with reduced anthropic interference. According to Koproski et al. (2006), the death of large animals is more common when the fires are large and spread fast, isolating them and preventing them from escaping, or when thick clouds of smoke are produced. Large fires that affect extensive areas are more oftenstrongly associated with high emigration rates in comparison to small fires in limited areas (LyON et al. 2000).

\section{ACKNOWLEDGMENTS}

To Coordenação de Aperfeiçoamento de Pessoal de Nível Superior, Florestal Vale do Corisco Ltda and Bio situ Projetos e Estudos Ambientais Ltda for the financial support.

\section{LITERATURE CITED}

Bowyer, R.T.; V.V. BAllenberghe \& K.R. Rock.1994. Scent marking by Alaskan moose: characteristics and spatial distribution of rubbed trees. Canadian Journal of Zoology 72: 2186-2192.

Cabrera, A. \& J. Yepes. 1960. Mamiferos Sudamericanos. Buenos Aires, Ediar, vol. 2, 160p.

Chebez, J.C. 1994. Yurumí, p.184-190. In: J.C. Chebez (Ed.). Los que se Van. Buenos Aires, Albatros, 606p.

Emmons, L.H. 1997. Neotropical rainforest mammals: a field guide. Chicago, University of Chicago Press, 307p.

Fonseca, G.A.B. \& J.M. Aguiar. 2004. The 2004 Edentate Species Assessment Workshop. Edentata 6: 1-26.

Fonseca, G.A.B.; A.B. Rylands; C.M.R. Costa; R.B. Machado \& Y.L.R. Leite. 1994. Livro vermelho dos mamíferos brasileiros ameaçados de extinção. Belo Horizonte, Biodiversitas, 460p.
IвAмA. 2003. Lista da fauna brasileira ameaçada de extinção. Available online at: www.ibama.gov.br/fauna/downloads/ lista\%20spp.pdf [Acessed: 25/III/2008].

IUCN. 2008. 2008 IUCN Red List of Threatened Species. Available online at: http://www.iucnredlist.org/apps/redlist/ details/14224/0 [Acessed: 9/X/2008].

Koproski, L.; P.P. Mangini; J.R. Pachaly; A.C. Batista \& R.V. Soares. 2006. Impacto do fogo sobre serpentes (Squamata) no Parque Nacional de Ilha Grande (PR/MS), Brasil. Arquivos de Ciências Veterinárias e Zoologia da Unipar 9: 30-40.

Lyon, L.J.; E.S. Telfer \& D.S. Schreiner. 2000. Direct effects of fire and animal response, p. 17-23. In: L.J. Lyon; M.H. HufF; R.G. Hooper; E.S. Telfer; D.S. Schreiner \& J.K. Smith (Eds). Wildland fire in ecosystems: effects of fire on fauna. Ogden, USDA, Forest Service, Rocky Moutain Research Station, 113p.

MAACK, R. 1981. Geografia Física do estado do Paraná. Rio de Janeiro, J. Olympio Secretaria da Cultura e do Esporte do Estado do Paraná, $2^{\text {nd }}$ ed., 442p.

Margarido, T.C.C. \& F.G. Braga. 2004. Mamíferos. In: S.B. Мikich $\&$ R.S. BÉRnILS (Eds). Livro vermelho da fauna ameaçada no estado do Paraná. Curitiba, Instituto Ambiental do Paraná, 762p.

Moro, R.S. \& M.R.B. Do CARMO. 2007. A vegetação campestre nos Campos Gerais, p. 93-98. In: M.S. Melo; R.S. Moro \& G.B. Guimarães (Eds). Patrimônio Natural dos Campos Gerais do Paraná. Ponta Grossa, Editora Universidade estadual de Ponta Grossa, 230p.

NoWAK, R.M. 1991. Walker's mammals of the world. Baltimore, The Johns Hopkins University Press, $5^{\text {th }}$ ed., 1629p.

Parera, A. 2002. Los Mamíferos de la Argentina y La Región Austral de Sudamérica. Buenos Aires, El Ateneo, 453p.

RedFord, K.H. 1985. Emas National Park and the plight of the Cerrados. Oryx 19 (4): 210-214.

Roberts, S.C. 1997. Selection of scent-marking sites by klipspringers (Oreotragus oreotragus). Journal of Zoology 243: 555-564.

Rossoni, R.B.; R.S. Machado \& A.B.M. Machado. 1981. Autonomic inervation of salivary glands in the armadillo, anteater and sloths (Edentata). Journal of Morphology 168: 316-317.

SANTOS, R.E.F. 2007. Novo registro documentado do galito Alectrurus tricolor (Vieillot, 1816) para o estado do Paraná, Brasil. Atualidades Ornitológicas 140: 13-14.

Shaw, J.H.; T.S. Carter \& J.C. Machado-Neto. 1985. Ecology of the Giant anteater Myrmecophaga tridactyla in Serra da Canastra, Minas Gerais, Brazil: a pilot study, p. 379-384. In: G.G. Montgomery (Ed.). The evolution and ecology of armadillos, sloths and vermilinguans. Washington, Smithsonian Institution Press, 451p.

Silveira, L.; F.H.G. Rodrigues; A.T.D. Jacomo \& J.H.F. Diniz. 1999. Impact of wildfires on the megafauna of Emas National Park, central Brazil. Oryx 33 (2): 108-114.

Veloso, H.P.; A.L.R. Rangel Filho \& J.C.A. Lima. 1991. Classifi- 
cação da vegetação brasileira adaptada a um sistema universal. Rio de Janeiro, IBGE, Departamento de Recursos Naturais e Estudos Ambientais, 124p.

VieirA, C. 1949. Xenartros e Marsupiais do Estado de São Paulo. Arquivos de Zoologia 7 (3): 325-362.

Weirich Neto, P.H. \& C.H. Rocha. 2007. Caracterização da produção agropecuária e implicações ambientais nos Campos Gerais, p. 181-190. In: M.S. Melo; R.S. Moro \& G.B. GuimaRÃES (Eds). Patrimônio Natural dos Campos Gerais do
Paraná. Ponta Grossa, Editora Universidade Estadual de Ponta Grossa, 230p.

Young, R.J.; C.M. Coelho \& D.R. Wieloch. 2003. A note on the climbing abilities of giant anteaters, Myrmecophaga tridactyla (Xenarthra, Myrmecophagidae). Boletim do Museu de Biologia Mello Leitão, Nova Série, 15: 41-46.

Ziller, S.R. \& F. GaLVÃo. 2002. A degradação da estepe gramíneolenhosa no Paraná por contaminação biológica de Pinus elliotti e Pinus taeda. Floresta 32 (1): 41-47.

Submitted: 15.III.2009; Accepted: 11.XII.2009.

Editorial responsibility: Kleber del Claro 